\title{
EFEKTIFITAS PENGGUNAAN LAHAN PARKIR KENDARAAN DI OBYEK WISATA PANTAI LASIANA KUPANG YANG BERDAMPAK PADA PENINGKATAN PENDAPATAN MASYARAKAT DAN PEMERINTAH DAERAH KOTA MADYA KUPANG
}

\author{
Obed Oktafianus Nego Nenobais ${ }^{1}$, Yohan A.A Lada ${ }^{2}$
}

\begin{abstract}
Abstrak :
Obyek Wisata Pantai Lasiana Kupang memiliki lahan parkir namun belum dimanfaatkan secara optimal. Kendaraan pengunjung masih parkir di sembarang tempat. Berdasarkan hal ini peneliti mengkaji, merumuskan suatu pembaharuan agar optimal dan bernilai ekonomis. Tujuan penelitian ini : 1) Menilai sejauhmana lahan parkir dipakai parkir kendaraan; 2) Merencanakan tambahan lahan parkir, 3) Merumuskan kebijakan pengelolaan lahan parkir yang sudah tersedia maupun lahan parkir tambahan yang efektif, ekonomis di obyek wisata Pantai Lasiana Kupang sehingga meningkatkan pendapatan masyarakat dan pemerintah daerah Kota Madya Kupang. Penelitian ini menggunakan metode survei dan deskriptif. Teknik pengumpulan data melalui wawancara, pengisian kuesioner, observasi. Kuesioner bagi pengunjung meliputi jenis alat transportasi, fasilitas lahan parkir. Kuesioner bagi pihak pengelola meliputi jumlah pengunjung, jenis kendaraan dan pelayanan parkiran kendaraan. Pengambilan data berupa jenis, jumlah kendaraan masuk keluar dan menggunakan lahan parkir, durasi parkir. Data dianalisis dengan statistik deskriptif. Hasilnya 78,4\% sepeda motor dipakai pengunjung dan yang parkir sembarang 44\%, mobil 53\%. Durasi rata-rata mobil 55,91 menit, sepeda motor 68,90 menit.Tersedia 200 satuan ruang parkir. Pendapatan parkir dalam setahun Rp. 149.056.875. Pendapatan tukang parkir Rp. 1.431.270. per bulan. 63\% responden memilih kurang bersih dan tidak ada petugas parkir. $80 \%$ responden memilih kurang memuaskan sistem pengaman parkir yang baik.
\end{abstract}

Kata-kata kunci : Parkir; Lahan parkir; Durasi parkir; Tarif; Pengunjung.

\section{PENDAHULUAN}

Kota Madya Kupang sebagai pintu masuk rute perjalanan Sail Komodo 2013, memiliki beberapa lokasi obyek wisata. Satu obyek wisata alam yang terkenal adalah Pantai Lasiana, yang mulai dibuka pada tahun 1970-an. Luas arealnya sekitar 3,5 hektar, ditumbuhi 65 pohon kelapa dan 230 pohon lontar tua yang hingga kini masih produktif. Lokasinya hanya berjarak $12 \mathrm{~km}$ dari pusat kota.

Kondisi fisiknya berpasir putih, ada perbukitan di bagian Barat. Airnya jernih, biru dengan debur ombak yang bergulung-gulung kecil dan tenang. Keindahan pantai ini karena karakter alamnya, sehingga menjadi alternatif pilihan bagi masyarakat kota Kupang melepaskan 


\section{2 | JUTEKS Jurnal Teknik Sipil Volume 2 Nomor 1 April 2017}

kepenatan untuk mandi, berenang, berjemur, bermain bola, makan jagung bakar, pisang gepe dan minum es kelapa muda di kala menjalani libur. Di pesisir pantai juga terdapat pondokpondok yang disebut Lopo-lopo, tempat berteduh.

Pintu gerbang masuk dijaga oleh petugas (pegawai) dari Dinas Pariwisata Kota Madya Kupang. Informasi dari petugas jaga pada hari biasa jumlah pengunjung bisa mencapai 100 orang, sedangkan pada hari libur bisa melebihi 500 pengunjung. Harga karcis Rp. 1.000,- per orang untuk anak-anak, dewasa Rp. 2.000,-per orang, kendaraan yang dipakai pengunjung dikenakan biaya parkir sebesar Rp. 1.000,untuk sepeda motor dan Rp. 2.000,- untuk mobil.

Pantai Lasiana ini memiliki areal parkir. Areal parkir yang pertama dekat pintu gerbang masuk dengan ukuran panjang 100 meter dan lebar 40 meter. Tempat parkir yang kedua di sebelah ujung Timur areal wisata ini dengan ukuran panjang 50 meter dan lebar 25 meter. Kedua lokasi parkir ini ada jalan penghubung selebar 2 meter dan beraspal.

Kedua tempat parkir ini juga tidak difungsikan secara optimal oleh para pengunjung yang menggunakan kendaraan. Para pengunjung memarkirkan kendaraan sesuka hati, atau bisa dikata semrawut. Hampir di seluruh areal Pantai Lasiana ada kendaraan yang diparkir. Pengunjung kadang memanfaatkan ruang atau celah kosong di antara pohon-pohon lontar dan kelapa untuk memarkirkan kendaraannya. Pada hal itu berbahaya, disamping itu merusak pemandangan bebas bagi para pengunjung yang ingin menikmati suasana pantai secara alamiah.

Berdasarkan kebiasaan parkir kendaraan di obyek wisata Pantai Lasiana saat ini, maka peneliti ingin mengkaji sejauhmana keefektifan parkir yang sesuai, merencanakan dan merumuskan kebijakan parkir yang efektif, ekonomis, rapih di obyek wisata Pantai Lasiana Kupang, sehingga diharapkan dapat meningkatkan pendapatan ekonomi masyarakat dan pemerintah daerah.
Adapun tujuan dari penelitian ini adalah : (1) Menilai sejauhmana lahan parkir yang tersedia dipakai parkir kendaraan yang masuk obyek wisata Pantai Lasiana Kupang; (2) Merencanakan tambahan lahan parkir di obyek wisata pantai Lasiana Kupang; (3) Merumuskan kebijakan pengelolaan terhadap lahan parkir yang sudah tersedia maupun lahan parkir tambahan yang efektif, ekonomis di wilayah obyek wisata Pantai Lasiana Kupang sehingga meningkatkan pendapatan masyarakat dan pemerintah daerah Kota Madya Kupang.

Kemanfaatan dari penelitian ini dapat digunakan sebagai salah satu model penerapan pola parkir yang efektif, efisien dalam rangka meningkatkan pendapatan asli daerah dan masyarakat sekitarnya.

\section{Parkir}

Pengertian parkir menurut Anonim (2013) adalah keadaan tidak bergerak suatu kendaraan yang bersifat sementara karena ditinggalkan oleh pengemudinya. Pengertian parkir menurut Kamus Besar Bahasa Indonesia (2008), tempat memarkir (menghentikan atau menaruh) kendaraan untuk beberapa saat.

Kegagalan menyediakan fasilitas parkir yang pantas untuk menampung permintaan akan menghasilkan penumpukan kendaraan dan kekecewaan. Untuk mengetahui kebutuhan akan tempat parkir harus dilakukan survei. Informasi yang sangat dibutuhkan bagi keperluan ini meliputi: a). klasifikasi kebutuhan serta jumlahnya; b). klasifikasi kendaraan, mobil penumpang,sepeda motor, bis, truk dan lain-lain; c). Kondisi tempat parkir : legal, ilegal, di pinggir jalan, diluar jalan, dan lain-lainl d). Waktu untuk parkir dan waktu keluar daerah parkir; e). Tujuan pengendara setelah menaiki kendaraannya; f). Tujuan lain setelah memanfaatkan tempat parkir; g). Kebutuhan akan tempat parkir.

Penentuan kebutuhan parkir berdasarkan Anonim (1998) dibedakan atas :

a. Kegiatan parkir yang tetap :1) Pusat pedagangan; 2) Pusat perkantoran swasta atau 
Dan Pemerintah Daerah Kota Madya Kupang

pemerintahan ; 3) Pusat pedagangan eceran atau pasar swalayan; 4) Pasar; 5) Sekolah; 6) Tempat rekreasi; 7) Hotel dan tempat penginapan; 8) Rumah sakit.
b.Kegiatan parkir yang bersifat sementara : 1) Bioskop; 2) Tempat pertunjukan; 3) Tempat pertandingan olahraga; 4) Rumah ibadah.

Ukuran kebutuhan ruang parkir di tempat rekreasi tertera pada Tabel 2.1 berikut ini.

Tabel 2.1. Kebutuhan satuan ruang parkir di tempat rekreasi

\begin{tabular}{|c|c|c|c|c|c|c|c|c|c|}
\hline $\begin{array}{c}\text { Luas Areal } \\
\text { Total } \\
\left(100 \mathrm{~m}^{2}\right)\end{array}$ & 50 & 100 & 150 & 200 & 400 & 800 & 1600 & 3200 & 6400 \\
\hline $\begin{array}{c}\text { Kebutuhan } \\
\text { Satuan } \\
\text { Ruang Parkir }\end{array}$ & 103 & 109 & 115 & 122 & 146 & 146 & 295 & 494 & 892 \\
\hline
\end{tabular}

Sumber : Anonim,1998

\section{Karakterisitk parkir}

Munawar (2009), menguraikan bahwa karakteristik parkir terdiri atas :

i. Akumulasi parkir

Akumulasi parkir adalah jumlah kendaraan yang diparkir di suatu tempat pada waktu tertentu dan dapat dibagi sesuai dengan kategori jenis maksud perjalanan. Perhitungan akumulasi parkir menggunakan rumus :

$$
\text { Akumulasi }=\mathrm{Ei}-\mathrm{Ex} \text {, }
$$

Dimana :

$\mathrm{Ei}=$ Entry (kendaraan yang masuk lokasi) Ex $=$ Exit (kendaraan yang keluar lokasi) Bila sebelum pengamatan sudah terdapat kendaraan yang parkir maka banyaknya kendaraan yang telah parkir dijumlahkan dalam harga akumulasi parkir yang telah dibuat, sehingga menghasilkan persamaan:

$$
\text { Akumulasi }=\mathrm{Ei}-\mathrm{Ex}+\mathrm{X} \text {, }
$$

Dimana : $\mathrm{X}=$ jumlah kendaraan yang telah diparkir sebelum pengamatan

ii. Durasi parkir

Durasi parkir yaitu rentang waktu sebuah kendaraan parkir di suatu tempat (dalam satuan menit atau jam). Nilai durasi parkir diperoleh dengan persamaan :

Durasi $=$ Extime - Entime,

Dimana :

Extime $=$ waktu saat kendaraan keluar dari lokasi parkir

Entime $=$ waktu saat kendaraan masuk ke lokasi parkir

iii. Pergantian parkir Pergantian parkir (turnover parking), yaitu tingkat penggunaan ruang parkir dan diperoleh dengan membagi volume parkir dengan jumlah ruang-ruang parkir untuk satu periode tertentu. Besarnya pergantian parkir dihitung dengan persamaan :

$$
\text { Tingkat turn over }=\frac{\text { Volume parkir }}{\text { Ruang parkir tersedia }}, \ldots . . . .
$$

iv. Indeks parkir

Indeks parkir adalah ukuran untuk menyatakan penggunaan panjang jalan dan dinyatakan dalam persentase ruang yang ditempati oleh kendaraan parkir. Besarnya indeks parkir dapat dihitung dengan persamaan berikut : 


$$
\text { Indeks parkir }=\frac{\text { Akumulasi parkir X 100\% }}{\text { Ruang parkir tersedia }}, \ldots
$$

v. Rata-rata durasi parkir

Perhitungan rata-rata durasi parkir dihitung dengan persamaan berikut :

$$
\mathrm{D}=\frac{\sum_{\mathrm{i}=1}^{\mathrm{n}} \mathbf{d}_{\mathrm{i}}}{\mathbf{n}}
$$

Dimana :

$\mathrm{D}=$ rata-rata durasi parkir kendaraan $\mathrm{d}_{\mathrm{i}}=$ durasi kendaraan ke $-\mathrm{i}$ (dari 1 hingga ke n)

vi. Jumlah ruang parkir yang dibutuhkan. Jumlah ruang parkir yang dibutuhkan dapat dihitung dengan persamaan berikut

$$
Z=\frac{Y \times D}{T}
$$

Dimana :

$\mathrm{Z}=$ ruang parkir yang dibutuhkan

$\mathrm{Y}=$ jumlah kendaraan parkir dalam satu waktu

$\mathrm{D}=$ rata-rata durasi (jam)

$\mathrm{T}=$ lama survei $(\mathrm{jam})$.

\section{Satuan ruang parkir}

Satuan ruang parkir (SRP) menurut Anonim (1998), adalah ukuran luas efektif untuk meletakkan kendaraan (mobil penumpang, bus/truk, atau sepeda motor), termasuk ruang bebas dan lebar buka pintu. Berdasarkan kebutuhan tersebut maka didapat ketentuan satuan ruang parkir untuk mobil penumpang seperti pada tabel berikut :

Tabel 2.2. Penentuan SRP ( Satuan Ruang Parkir )

\begin{tabular}{|c|l|l|}
\hline No & \multicolumn{1}{|c|}{ Jenis Kendaraan } & \multicolumn{1}{c|}{ SRP $\left(\mathrm{m}^{2}\right)$} \\
\hline \multirow{2}{*}{1} & a. Mobil Penumpang Untuk Golongan 1 & $2,3 \times 5$ \\
\cline { 2 - 3 } & b. Mobil Penumpang Untuk Golongan II & $2,5 \times 5$ \\
\cline { 2 - 3 } & c. Mobil Penumpang Untuk Golongan III & $3,0 \times 5$ \\
\hline 2 & Bus atau Truk & $3,4 \times 12,5$ \\
\hline 3 & Sepeda Motor & $0,75 \times 2$ \\
\hline
\end{tabular}

Sumber : Pedoman Perencanaan dan Pengoperasian Fasilitas Parkir, 1998

SRP untuk mobil penumpang ditunjukkan pada gambar berikut :

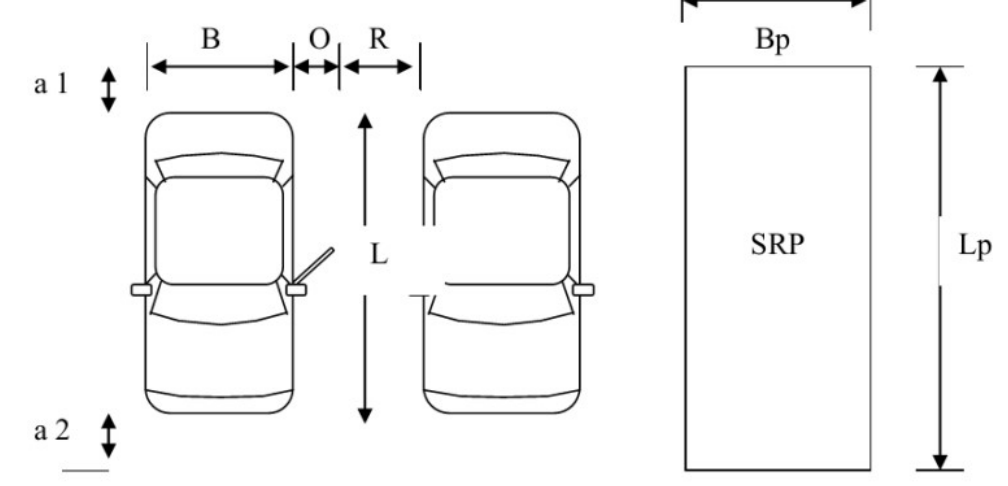

Keterangan :

$\mathrm{B}=$ Lebar total kendaraan ; $\mathrm{L}=$ Panjang total; $\mathrm{O}=$ Lebar bukaan pintu arah longitudinal; a 1 , a 2 = Jarak bebas $; \mathrm{R}=$ Jarak bebas arah lateral; Bp = Lebar SRP;Lp

$=$ Panjang SRP

Gambar 2.1. Penentuan SRP untuk mobil penumpang 
Nenobais ${ }^{1}$, Lada $^{2}$, Efektifitas Penggunaan Lahan Parkir Kendaraan Di Obyek Wisata Pantai Lasiana Kupang Yang Berdampak pada Peningkatan Pendapatan Masyarakat Dan Pemerintah Daerah Kota Madya Kupang

Tabel 2.3. Nilai SRP untuk mobil penumpang

\begin{tabular}{|c|l|l|l|}
\hline $\begin{array}{c}\text { Ukuran Mobil } \\
\text { penumpang }\end{array}$ & \multicolumn{3}{|c|}{ Dimensi } \\
\hline Golongan I & $\begin{array}{l}\mathrm{B}=170 \\
\mathrm{O}=55 \\
\mathrm{R}=5\end{array}$ & $\begin{array}{l}\mathrm{a} 1=10 \\
\mathrm{~L}=470 \\
\mathrm{a} 2=20\end{array}$ & $\begin{array}{l}\mathrm{Bp}=230=\mathrm{B}+\mathrm{O}+\mathrm{R} \\
\mathrm{L}=500=\mathrm{L}+\mathrm{a} 1+\mathrm{a} 2\end{array}$ \\
\hline Golongan II & $\mathrm{B}=170$ & $\mathrm{a} 1=10$ & $\mathrm{Bp}=250=\mathrm{B}+\mathrm{O}+\mathrm{R}$ \\
& $\mathrm{O}=75$ & $\mathrm{~L}=470$ & $\mathrm{ap}=500=\mathrm{L}+\mathrm{a} 1+\mathrm{a} 2$ \\
& $\mathrm{R}=5$ & $\mathrm{a} 1=10$ & $\mathrm{Bp}=300=\mathrm{B}+\mathrm{O}+\mathrm{R}$ \\
& $\mathrm{B}=170$ & $\mathrm{~L}=470$ & $\mathrm{~L}=500=\mathrm{L}+\mathrm{a} 1+\mathrm{a} 2$ \\
\hline Golongan III & $\mathrm{O}=80$ & $\mathrm{R}=50$ & \\
\hline
\end{tabular}

Sumber : Munawar (2009)

Satuan Ruang Parkir untuk Bus/Truk dapat dilihat dalam Gambar berikut ini.
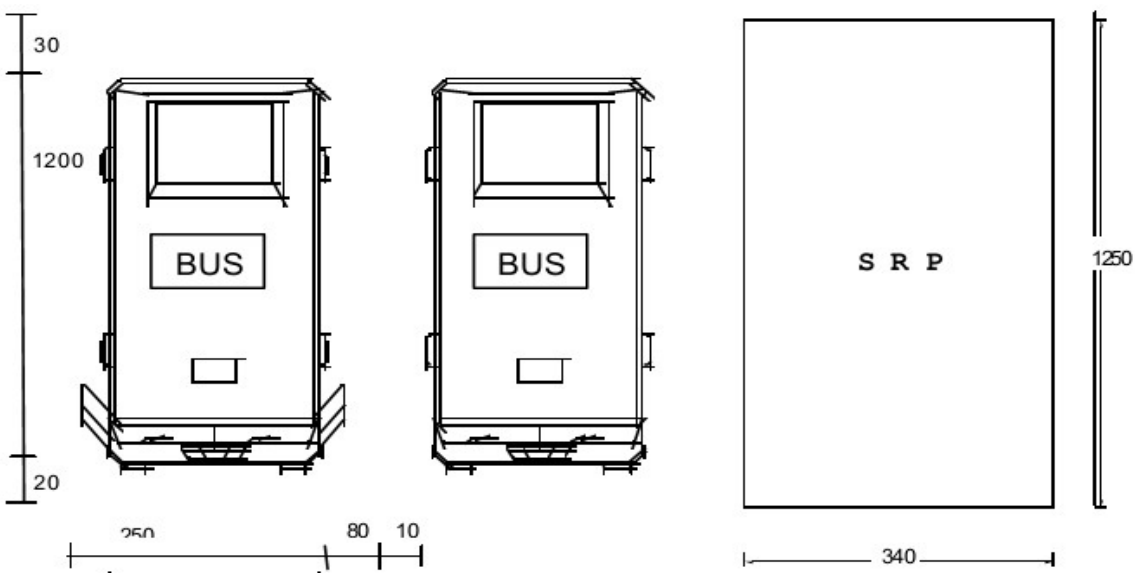

Gambar 2.2. Satuan Ruang Parkir (SRP) untuk Bus/Truk (dalam cm)

Tabel 2.4. Dimensi SRP untuk kendaraan truk / bus

\begin{tabular}{|c|c|c|c|}
\hline $\begin{array}{c}\text { Ukuran Bus/ } \\
\text { truk }\end{array}$ & \multicolumn{3}{|c|}{ Dimensi } \\
\hline Kecil & $\begin{array}{l}\mathrm{B}=170 \\
\mathrm{O}=80 \\
\mathrm{R}=30\end{array}$ & $\begin{array}{l}\mathrm{a} 1=10 \\
\mathrm{~L}=470 \\
\mathrm{a} 2=20\end{array}$ & $\begin{array}{l}\mathrm{Bp}=300=\mathrm{B}+\mathrm{O}+\mathrm{R} \\
\mathrm{Lp}=500=\mathrm{L}+\mathrm{a} 1+\mathrm{a} 2\end{array}$ \\
\hline Sedang & $\begin{array}{l}\mathrm{B}=200 \\
\mathrm{O}=80 \\
\mathrm{R}=40\end{array}$ & $\begin{array}{l}\text { a1 }=20 \\
L=800 \\
\text { a2 }=20\end{array}$ & $\begin{array}{l}\mathrm{Bp}=320=\mathrm{B}+\mathrm{O}+\mathrm{R} \\
\mathrm{Lp}=500=\mathrm{L}+\mathrm{a} 1+\mathrm{a} 2\end{array}$ \\
\hline
\end{tabular}


6 | JUTEKS Jurnal Teknik Sipil Volume 2 Nomor 1 April 2017

\begin{tabular}{|l|l|l|c|}
\hline Besar & $\mathrm{B}=250$ & $\mathrm{a} 1=30$ & $\mathrm{Bp}=380=\mathrm{B}+\mathrm{O}+\mathrm{R}$ \\
& $\mathrm{O}=80$ & $\mathrm{~L}=1200$ & $\mathrm{Lp}=1250=\mathrm{L}+\mathrm{a} 1+\mathrm{a} 2$ \\
& $\mathrm{R}=50$ & $\mathrm{a} 2=20$ & \\
\hline
\end{tabular}

Sumber : Munawar (2009)

SRP untuk sepeda motor dapat dilihat dalam Gambar berikut ini.

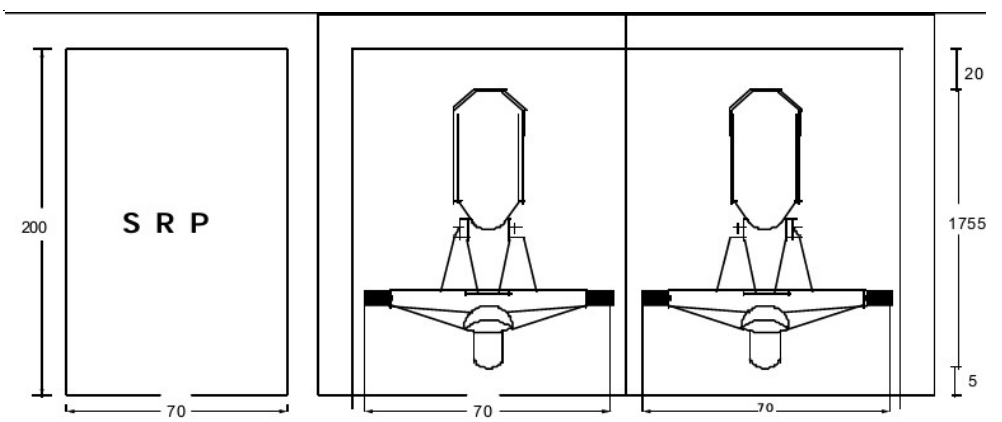

Gambar 2.3. Satuan Ruang Parkir (SRP) untuk Sepeda Motor (dalam cm)

Sumber : Anonim (1998)

\section{$>$ Pola Parkir Kendaraan}

Kendaraan yang dipakai pengguna jalan memerlukan area parkir di lokasi tujuan. Area parkir yang tersedia ditata untuk memberikan akses keluar masuk kendaraan secara aman dan efisien. Anonimus (1998) menguraikan pola parkir sesuai jenis kendaraan di tempat kegiatan. Beberapa kriteria desain parkir di luar badan jalan seperti di taman parkir adalah: a). Rencana Umum Tata Ruang Daerah (RUTRD); b). keselamatan dan kelancaran lalu lintas; c).kelestarian lingkungan; d).kemudahan bagi pengguna jasa; e). tersedianya tata guna lahan; f). letak antara jalan akses utama dan daerah yang dilayani.

Selanjutnya Anonim (1998), menguraikan beberapa pola parkir sesuai jenis kendaraan, dan kondisi lokasi parkir. Jika area parkir seperti di taman pola sebagai berikut :

1.Parkir kendaraan satu sisi. Pola parkir ini diterapkan apabila ketersediaan ruang sempit.

a)Membentuk sudut $90^{\circ}$. Pola parkir ini mempunyai daya tampung lebih banyak jika dibandingkan dengan pola parkir paralel, tetapi kemudahan dan kenyamanan pengemudi melakukan manuver masuk dan keluar ke ruangan parkir lebih sedikit jika dibandingkan dengan pola parkir dengan sudut yang lebih kecil dari $90^{\circ}$.

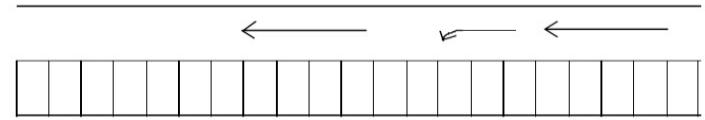

Gambar 2.4. Pola parkir kendaraan satu membentuk sudut $90^{\circ}$

Sumber : Anonim (1998)

b)Membentuk sudut $30^{\circ}, 45^{\circ}, 60^{\circ}$. Pola parkir ini mempunyai daya tampung lebih banyak jika dibandingkan dengan pola parkir paralel, dan kemudahan dan kenyamanan pengemudi melakukan manuver masuk dan keluar ke ruangan parkir lebih besar jika dibandingkan dengan pola parkir dengan sudut $90^{\circ}$.

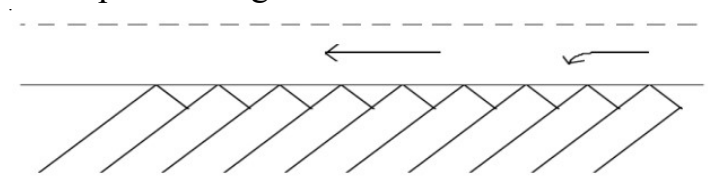

Gambar 2.5. Pola parkir kendaraan satu membentuk sudut $30^{\circ}, 45^{\circ}, 60^{\circ}$

Sumber : Anonim (1998) 
Nenobais ${ }^{I}$, Lada $^{2}$, Efektifitas Penggunaan Lahan Parkir Kendaraan Di Obyek Wisata Pantai Lasiana

Kupang Yang Berdampak pada Peningkatan Pendapatan Masyarakat

Dan Pemerintah Daerah Kota Madya Kupang

2.Parkir kendaraan dua sisi. Pola parkir ini diterapkan apabila ketersediaan ruang cukup memadai.

a)Membentuk sudut $90^{\circ}$. Pada pola parkir ini, arah gerakan lalu lintas kendaraan dapat satu arah atau dua arah.

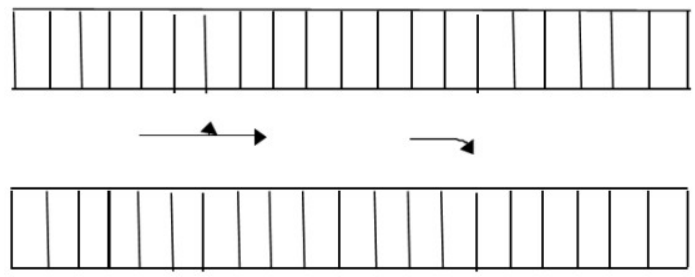

Gambar 2.6. Parkir mobil penumpang membentuk sudut $90^{\circ}$

Sumber : Anonim (1998)

b)Membentuk sudut kurang dari $90^{\circ}$. Pola parkir ini lebih cocok untuk mobil penumpang, bis dan truk.

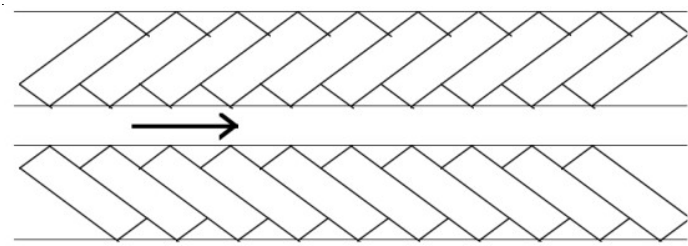

Gambar 2.7. Parkir mobil penumpang membentuk sudut $30^{\circ}, 45^{\circ}$ dan $60^{\circ}$

Sumber : Anonim (1998)

3.Jalur Sirkulasi, Gang, dan Modul

Perbedaan antara jalur sirkulasi dan jalur gang terutama terletak pada penggunaannya.
Patokan umum yang dipakai adalah :

a. panjang sebuah jalur gang tidak lebih dari 100 meter;

b.jalur gang yang ini dimaksudkan untuk melayani lebih dari 50 kendaraan dianggap sebagai jalur sirkulasi.

Lebar minimum jalur sirkulasi

a. untuk jalan satu arah $=3,5$ meter,

b.untuk jalan dua arah $=6,5$ meterepeda motor

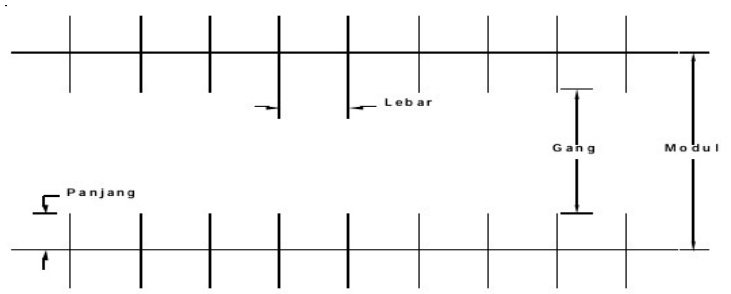

Gambar 2. 8. Lebar jalur, gang, modul jika parkir dua sisi sudut $90^{\circ}$.

Sumber : Anonim (1998)

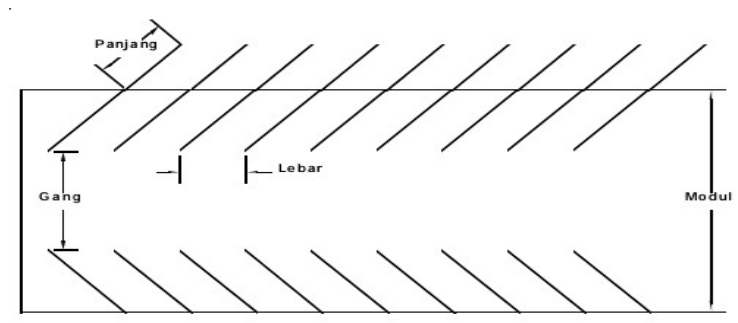

Gambar 2. 9. Lebar jalur, gang, modul jika parkir dua sisi $<90^{\circ}$

Sumber : Anonim (1998)

Nilai besaran gang, jalur dan modul tertera dalam Tabel berikut ini.

Tabel 2.5. Lebar jalur gang

\begin{tabular}{|c|c|c|c|c|c|c|c|c|}
\hline \multirow{3}{*}{ S R P } & \multicolumn{8}{|c|}{ Lebar Jalur Gang (m) } \\
\hline & \multicolumn{2}{|c|}{$<30^{\circ}$} & \multicolumn{2}{|c|}{$<45^{0}$} & \multicolumn{2}{|c|}{$<60^{\circ}$} & \multicolumn{2}{|c|}{$90 \%$} \\
\hline & 1 arah & 2 arah & 1 arah & 2 arah & 1 arah & 2 arah & 1 arah & $\begin{array}{c}2 \\
\text { arah }\end{array}$ \\
\hline a. SRP mobil pnp & $3,0^{*}$ & $6,00^{*}$ & 3,00 & $6,00^{*}$ & $5,1^{*}$ & $6,00^{*}$ & 6. * & $8,0^{*}$ \\
\hline $2,5 \mathrm{~m} \times 5,0 \mathrm{~m}$ & $3,50^{\star \star}$ & $6,50^{* *}$ & $3,50^{* \star}$ & $6,50^{\star \star}$ & $5,1^{\star *}$ & $6,50^{\star *}$ & $6,5^{* *}$ & 8,0 ** \\
\hline b. SRP mobil pnp & $3,0^{*}$ & $6,00^{*}$ & 3,00 & $6,00^{*}$ & $4,60^{*}$ & $6,00^{*}$ & 6. * & 8,0 * \\
\hline $2,5 \mathrm{~m} \times 5,0 \mathrm{~m}$ & $3,50^{* \star}$ & $6,50^{\star *}$ & 3,50 ** & $6,50^{\star \star}$ & $4,60^{* *}$ & $6,50^{\star \star}$ & $6,5^{* \star}$ & 8,0 ** \\
\hline $\begin{array}{c}\text { c. SRP sepeda } \\
\text { motor } 0,75 \times 30 \mathrm{~m}\end{array}$ & & & & & & & & $\begin{array}{l}1,6^{*} \\
1,6^{* *}\end{array}$ \\
\hline $\begin{array}{l}\text { d. SRP bus/ truk } \\
3,40 \mathrm{~m} \times 12,5 \mathrm{~m}\end{array}$ & & & & & & & & 9,5 \\
\hline
\end{tabular}

Keterangan : * = lokasi parkir tanpa fasilitas pejalan kaki

$* *=$ lokasi parkir dengan fasilitas pejalan kaki

Sumber : Anonim (1998) 


\section{\begin{tabular}{l|l}
8 & JUTEKS Jurnal Teknik Sipil
\end{tabular}}

\section{$>$ Efektifitas parkiran}

Kata Efektifitas menurut Westra (1989) dalam Putri (2011), berasal dari kata efektif yang berarti terjadinya suatu efek atau akibat yang dikehendaki oleh sesuatu perbuatan. Efektif dalam Kamus Besar Bahasa Indonesia berarti dapat membawa hasil, berhasil guna. Kriteria dalam menilai efektifitas menurut Handoko (1998) dalam Putri (2011) adalah : a). Kegunaan; b). Ketepatan dan objektivitas; c). Ruang lingkup; d). Efektifitas gaya; e). Akuntabilitas; f). Ketepatan waktu

Salah satu indikator dari efektifitas menurut Gibon dalam Putri (2011) adalah efisiensi. Efisiensi dapat dijelaskan sebagai angka perbandingan (ratio) antara out put dan in put, perbandingan antara keuntungan dan biaya atau dengan out put atau dengan waktu. Dalam hubungan dengan efektifitas parkiran maka out put berupa penggunaan lahan parkiran secara optimal, peningkatan ekonomi, kepuasan pengguna jasa dan peningkatan jumlah pengunjung. Input berupa penataan lahan parkir, penambahan lahan parkir, tarif parkir, pengatur parkir.

\section{$>$ Survei parkir \\ $>$ Survei inventarisasi ruang parkir}

Pelaksanaan survei inventarisasi ruang parkir menurut Abubakar, dkk (1999), adalah untuk mengetahui fasilitas ruang parkir yang tersedia. Informasi ini dijadikan dasar untuk mengetahui kebutuhan ruang parkir yang harus disediakan dan guna memenuhi kebutuhan untuk masa yang akan datang. Survei inventarisasi parkir yang lengkap meliputi jumlah, lokasi dan jenis ruang parkir.Cakupan studi meliputi : a). Ruang parkir untuk kendaraan pribadi di jalan baik yang dikendalikan maupun yang tidak dikendali-kan; b). Ruang parkir untuk kendaraan pribadi di luar jalan untuk kendaraan umum dan pribadi; c). Pemberhentian kendaraan; d).Lokasi bongkar muat barang dan parkir mobil barang

Inventarisasi menurut Abubakar, dkk (1999), juga harus mencatat sistem pengen- dalian yang dilaksanakan di areal parkir yang mencakup : a). Lokasi dimana parkir dilarang dan dibatasi; b).Waktu pengendalian, larangan dan pembatasan parkir; c).Tarif dan biaya parkir; d).Marka jalan, dimensi celukan dan sudut kemiringan parkir; e). Rambu jalan termasuk rambu yang tidak resmi.

\section{$>$ Survei kebutuhan parkir}

Survei kebutuhan parkir menurut Abubakar, dkk (1999) akan diperoleh informasi sebagian atau seluruh karakteristik-karakteristik berikut : kebutuhan parkir, maksud parkir, volume parkir, durasi parkir, akumulasi parkir, angka pergantian parkir (turnover), indeks parkir dan jarak berjalan (walking distance). Survei kebutuhan parkir dibedakan menjadi survei wawancara parkir dan survei observasi parkir.

Lebih lanjut Abubakar, dkk (1999), menguraikan bahwa survei wawancara ada empat bentuk yang biasa digunakan : a).Wawancara parkir; b).Survei kartu pos; c). Wawancara rumah tangga; d). Wawancara pada lokasi tertentu. Sedangkan survei observasi teknik yang digunakan adalah survei durasi parkir.

\section{$>$ Pengendalian Parkir \\ $>$ Kebijakan parkir}

Menurut Hobbs (1995) dalam Anonim (1998) pengendalian utama yang sejauh ini telah dibahas adalah mengenai ruang atau tempatnya. Akan tetapi harga dan biaya adalah penting juga mengingat pengendalian tersebut dapat digunakan secara bersama agar penawaran ruang parkir yang tersedia dapat disesuaikan dengan permintaan ruang, waktu, dan biaya. Parkir tidak diijinkan pada tempattempat dimana merupakan daerah berbahaya. Pengendalian dengan waktu dan biaya berkaitan dengan usaha untuk menyeim-bangkan penawaran dan permintaan, dan pembayaran kembali atas investasi keuangan untuk pembangunan prasarana dan perawatan. Kombinasikombinasi pengendalian yang utama adalah : a).Kebijakan tarif parkir; b). Diterapkan untuk tujuan memaksimalkan retribusi parkir; 
Dan Pemerintah Daerah Kota Madya Kupang

c).Pembatasan lokasi dan ruang; d). Dimaksudkan untuk mengendalikan arus lalulintas kendaraan pribadi ke suatu daerah tertentu atau untuk membebaskan suatu daerah atau koridor tertentu dari kendaraan yang parkir di pinggir jalan; e).Pembatasan waktu parkir pada suatu koridor untuk kelancaran arus lalu lintas; f). Pembatasan waktu lamanya parkir biasanya diwujudkan dengan penetapan tarif progresif menurut lamanya waktu parkir; g). Pembatasan-pembatasan pengeluaran ijin dan jenis kendaraan; h).Pembatasan waktu terhadap akses

Metode-metode pengendalian parkir yang utama dan umum dilakukan adalah dengan :

a). Alat pengukur parkir (parking meter);

b). Sistem kartu dan disk; c). Sistem karcis;

d). Sistem ijin parkir perumah.

\section{> Manfaat kebijakan parkir yang baik}

Kebijakan parkir dapat mengurangi space di pusat kota melalui pengenaan tarif parkir yang cukup tinggi. Hal ini dapat terjadi karena para pemilik kendaraan akan enggan menggunakan kendaraannya menuju pusat kota (mengingat tarif yang tinggi), sehingga parking policy dapat mengurangi konsumsi energi serta kemacetan lalu lintas. Di beberapa kota, kebijakan parkir telah mampu meningkatkan pemakaian angkutan umum diikuti pengurangan angka kemacetan.

Penerapan kebijakan parkir menurut Anonim (1998) harus dipantau sebelum dan sesudah pelaksanaannya. Disamping itu harus dilakukan evaluasi terhadap manfaat penerapan kebijakan parkir. Hasil pemantauan dijadikan masukan untuk penyempurnaan kebijakan lebih lanjut.

\section{METODOLOGI PENELITIAN}

\section{$>$ Lokasi Penelitian}

Penelitian ini dilakukan di Obyek wisata Pantai Lasiana Kupang, Kota Madya Kupang Propinsi Nusa Tenggara Timur.

\section{$>$ Tahapan Penelitian}

Penelitian ini difokuskan pada ketersediaan dan penggunaan lahan parkir yang optimal di obyek wisata di Kupang. Metode survei dan deskriptif yang dipakai dalam penelitian ini. Variabel penelitian terdiri atas ruang parkir, durasi parkir, maksud parkir, jenis dan jumlah kendaraan, waktu tempuh, jarak tempuh, pendapatan pengunjung. Sampel penelitian ini adalah para pengunjung yang dilakukan secara aksidental. Teknik pengumpulan data melalui wawancara, kuesioner, observasi dan dokumentasi. Analisis data menggunakan statistik deskriptif.

Tahapan penelitian ini dilakukan sebagai berikut :

- Melakukan identifikasi masalah ke lokasi obyek wisata

- Melakukan wawancara dengan pihak pengelola obyek wisata untuk mendapatkan informasi jumlah pengunjung dan alat transportasi yang dipakainya serta tarif / biaya karcis, serta perkembangan pengelolaan berbagai fasilitas pelayanan publik di obyek wisata, terutama pemanfaatan lahan parkir. Wawancara dengan pengunjung disertai pembagian kuesioner menyangkut alat transportasi yang dipakai (pribadi, umum), maksud perjalanan, maksud parkir, biaya dan pendapatan ekonominya.

- Mencatat jenis dan jumlah kendaraan yang masuk obyek wisata lalu diparkir di dalam maupun di luar area parkir, serta yang keluar obyek wisata.

- Mengolah data dikomputer, menilai keefektifitasan pemanfaatan lahan parkir.

\section{HASIL DAN PEMBAHASAN}

\section{$>$ Jenis dan Jumlah Kendaraan masuk Obyek wisata Pantai Lasiana}

Kendaraan yang dipakai pengunjung, prosentase dominan berkisar 60,5\% sampai $78,4 \%$ untuk jenis sepeda motor, sementara mobil $21,4 \%$ sampai $39,5 \%$, seperti tertera dalam Tabel .1 Dalam Tabel 2 menunjukkan 


\section{\begin{tabular}{l|l|llll}
$\square$ & 10 & JUTEKS Jurnal Teknik Sipil Volume 2 & Nomor 1 & April 2017
\end{tabular}}

bahwa kendaraan jenis sepeda motor yang parkir dalam area parkir yang tersedia berkisar dari $56 \%$ sampai $73 \%$, sementara jenis mobil berkisar dari $47 \%$ sampai $78 \%$. Kendaraan yang diparkirkan di luar area parkir yang tersedia untuk jenis sepeda motor mulai dari $27 \%$ sampai $44 \%$, mobil $22 \%$ sampai $53 \%$.

Tabel .1. Jenis dan Jumlah Kendaraan yang dipakai pengunjung ke obyek wisata Pantai Lasiana Kupang

\begin{tabular}{|c|c|c|c|c|c|c|c|c|c|c|c|}
\hline \multirow{3}{*}{ NO } & \multirow{3}{*}{ Hari/tanggal } & \multicolumn{10}{|c|}{ Jumlah dan prosentase kendaraan berdasarkan jenis } \\
\hline & & \multicolumn{2}{|c|}{ Sepeda motor } & \multicolumn{2}{|c|}{ Mobil } & \multicolumn{2}{|c|}{ Bis } & \multicolumn{2}{|c|}{ Truk } & \multicolumn{2}{|c|}{ TOTAL } \\
\hline & & \begin{tabular}{|l|} 
Jumlah \\
\end{tabular} & $\%$ & Jumlah & $\%$ & Jumlah & $\%$ & Jumlah & $\%$ & Jumlah & $\%$ \\
\hline 1 & Minggu, 7-8-2016 & 166 & $73,5 \%$ & 60 & $26,5 \%$ & 0 & $0,0 \%$ & 0 & $0,0 \%$ & 226 & $100 \%$ \\
\hline 2 & Sabtu, 13-8-2016 & 96 & $64,9 \%$ & 52 & $35,1 \%$ & 0 & $0,0 \%$ & 0 & $0,0 \%$ & 148 & $100 \%$ \\
\hline 3 & Minggu, 14-8-2016 & 326 & $78,4 \%$ & 89 & $21,4 \%$ & 0 & $0,0 \%$ & 1 & $0,2 \%$ & 416 & $100 \%$ \\
\hline 4 & Rabu, 17-8-2016 & 188 & $70,7 \%$ & 75 & $28,2 \%$ & 0 & $0,0 \%$ & 3 & $1,1 \%$ & 266 & $100 \%$ \\
\hline 5 & Kamis, 18-8-2016 & 63 & $69,2 \%$ & 28 & $30,8 \%$ & 0 & $0,0 \%$ & 0 & $0,0 \%$ & 91 & $100 \%$ \\
\hline 6 & Sabtu, 20-8-2016 & 101 & $60,5 \%$ & 66 & $39,5 \%$ & 0 & $0,0 \%$ & 0 & $0,0 \%$ & 167 & $100 \%$ \\
\hline 7 & Minggu, 21-8-2016 & 277 & $61,6 \%$ & 169 & $37,6 \%$ & 2 & $0,4 \%$ & 2 & $0,4 \%$ & 450 & $100 \%$ \\
\hline 8 & Minggu,28-8-2016 & 116 & $61,7 \%$ & 72 & $38,3 \%$ & 0 & $0,0 \%$ & 0 & $0,0 \%$ & 188 & $100 \%$ \\
\hline
\end{tabular}

Sumber : Hasil survei dan Perhitungan

Tabel.2. Prosentase Kendaraan Pengunjung Yang diparkir dalam kawasan Obyek wisata Pantai Lasiana

\begin{tabular}{|c|c|c|c|c|c|c|c|c|c|}
\hline \multirow{3}{*}{ NO } & \multirow{3}{*}{ Hari/tanggal } & \multicolumn{3}{|c|}{ Kendaraan parkir di dalam } & \multicolumn{3}{|c|}{$\begin{array}{c}\text { Kendaraan parkir di Luar } \\
\text { area parkir }\end{array}$} \\
\cline { 3 - 10 } & & SPM & Mobil & Bis & Truk & SPM & Mobil & Bis & Truk \\
\cline { 3 - 9 } & & $\%$ & $\%$ & $\%$ & $\%$ & $\%$ & $\%$ & $\%$ & $\%$ \\
\hline 1 & Minggu, 7-8-2016 & $69 \%$ & $65 \%$ & $0 \%$ & $0 \%$ & $31 \%$ & $35 \%$ & $0 \%$ & $0 \%$ \\
\hline 2 & Sabtu, 13-8-2016 & $64 \%$ & $60 \%$ & $0 \%$ & $0 \%$ & $36 \%$ & $40 \%$ & $0 \%$ & $0 \%$ \\
\hline 3 & Minggu, 14-8-2016 & $62 \%$ & $78 \%$ & $0 \%$ & $0 \%$ & $38 \%$ & $22 \%$ & $0 \%$ & $0 \%$ \\
\hline 4 & Rabu, 17-8-2016 & $72 \%$ & $60 \%$ & $0 \%$ & $0 \%$ & $28 \%$ & $40 \%$ & $0 \%$ & $100 \%$ \\
\hline 5 & Kamis, $18-8-2016$ & $60 \%$ & $61 \%$ & $0 \%$ & $0 \%$ & $40 \%$ & $39 \%$ & $0 \%$ & $0 \%$ \\
\hline 6 & Sabtu, 20-8-2016 & $66 \%$ & $47 \%$ & $0 \%$ & $0 \%$ & $34 \%$ & $\mathbf{5 3 \%}$ & $0 \%$ & $0 \%$ \\
\hline 7 & Minggu, 21-8-2016 & $56 \%$ & $62 \%$ & $100 \%$ & $0 \%$ & $44 \%$ & $38 \%$ & $0 \%$ & $100 \%$ \\
\hline 8 & Minggu,28-8-2016 & $73 \%$ & $63 \%$ & $0 \%$ & $0 \%$ & $27 \%$ & $38 \%$ & $0 \%$ & $0 \%$ \\
\hline
\end{tabular}

Sumber : Hasil survei dan Perhitungan

Berdasarkan wawancara didapatkan bahwa pengunjung yang menggunakan kendaraan ke lokasi obyek wisata, tidak mau parkir jauh, dengan alasan faktor keamanan, mendekatkan kendaraan dengan tempat kegiatan, karena tidak adanya petugas jaga yang mengatur pola parkir, serta belum ada tanda larangan parkir di sembarang tempat. Padahal dengan memarkirkan kendaraan di area bukan parkiran, akan mengganggu pemandangan dalam kawasan yang ditumbuhi sejumlah pohon tuak dan kelapa. Disamping itu ketika buah lontar atau kelapa yang sudah tua atau rusak jatuh dapat mencelakai manusia atau kendaraan yang parkir di sekitarnya. 
Nenobais ${ }^{1}$, Lada $^{2}$, Efektifitas Penggunaan Lahan Parkir Kendaraan Di Obyek Wisata Pantai Lasiana Kupang Yang Berdampak pada Peningkatan Pendapatan Masyarakat Dan Pemerintah Daerah Kota Madya Kupang

\section{$>$ Karakteristik Parkir Kendaraan}

Karakteristik parkir mobil dan sepeda motor dalam area parkir yang sudah ada di kawasan obyek wisata Pantai Lasiana Kupang seperti tersaji dalam Tabel 3.

Tabel3. Karakteristik Parkir Kendaraan dalam lahan parkir Yang tersedia di obyek wisata Pantai Lasiana Kupang

\begin{tabular}{|c|c|c|c|c|c|c|c|c|c|c|c|c|c|}
\hline \multirow[b]{2}{*}{ NO } & \multirow[b]{2}{*}{ Hari/tanggal } & \multicolumn{6}{|c|}{ Mobil } & \multicolumn{6}{|c|}{ Sepeda motor } \\
\hline & & Akumulasi & $\begin{array}{c}\text { Durasi } \\
\text { total mobil } \\
\text { (menit) }\end{array}$ & $\begin{array}{c}\text { Durasi } \\
\text { rata-rata } \\
\text { (menit) }\end{array}$ & $\begin{array}{c}\text { Durasi rata- } \\
\text { rata } 8 \text { hari } \\
\text { (menit) }\end{array}$ & $\begin{array}{c}\text { Indeks } \\
\text { parkir }\end{array}$ & $\begin{array}{l}\text { Ruang } \\
\text { parkir }\end{array}$ & Akumulasi & $\begin{array}{c}\text { Durasi } \\
\text { total } \\
\text { mobil } \\
\text { (menit) }\end{array}$ & $\begin{array}{c}\text { Durasi rata } \\
\text { rata } \\
\text { (menit) }\end{array}$ & $\begin{array}{c}\text { Durasi } \\
\text { rata-rata } \\
8 \text { hari } \\
\text { (menit) }\end{array}$ & $\begin{array}{l}\text { Indeks } \\
\text { parkir }\end{array}$ & $\begin{array}{l}\text { Ruang } \\
\text { parkir }\end{array}$ \\
\hline 1 & Minggu, 7-8-2016 & 44 & 2478,6 & \begin{tabular}{|l|}
56,33182 \\
\end{tabular} & \multirow{8}{*}{55,9076952} & 1,1 & 4,131 & 119 & 5087,4 & 42,751261 & \multirow{8}{*}{68,89535} & 2,975 & 8,479 \\
\hline 2 & Sabtu, 13-8-2016 & 29 & 1335,6 & 46,05517 & & 0,725 & 2,23 & 57 & 3734,4 & 65,515789 & & 1,425 & 6,224 \\
\hline 3 & Minggu, 14-8-2016 & 75 & 4471,2 & 59,616 & & 1,875 & 7,452 & 190 & 11971,2 & 63,006316 & & 4,75 & 19,95 \\
\hline 4 & Rabu, 17-8-2016 & 26 & 1401,6 & 53,90769 & & 0,65 & 2,336 & 101 & 10779 & 106,72277 & & 2,525 & 17,97 \\
\hline 5 & Kamis, 18-8-2016 & 18 & 1345,8 & \begin{tabular}{|l|}
74,76667 \\
\end{tabular} & & 0,45 & 2,243 & 40 & 3512,4 & 87,81 & & 1 & 5,85 \\
\hline 6 & Sabtu, 20-8-2016 & 29 & 570 & 19,65517 & & 0,75 & 0,95 & 69 & 5028 & 72,869565 & & 1,725 & 8,38 \\
\hline 7 & Minggu, 21-8-2016 & 61 & 2947,2 & 48,31475 & & 1,525 & 4,912 & 152 & 9732,6 & 64,030263 & & 3,8 & 16,22 \\
\hline 8 & Minggu,28-8-2016 & 42 & 3721,8 & \begin{tabular}{|l|}
88,61429 \\
\end{tabular} & & 1,05 & 6,203 & 88 & 4264,2 & 48,456818 & & 2,2 & 7,11 \\
\hline
\end{tabular}

Sumber : Hasil Survei dan Perhitungan

Berdasarkan hasil perhitungan di atas di dapat bahwa rata-rata durasi mobil selama pengamatan 8 hari sebesar 55,91 menit atau 0,93 jam. Sementara rata-rata durasi sepeda motor selama pengamatan 8 hari sebesar 68,90 menit atau 1,15 jam.

Berdasarkan durasi parkir akan diperoleh gambaran pengaturan parkiran. Ketika pengunjung yang menggunakan kendaraan parkir dalam area parkir yang tersedia, maka hal ini menunjukkan kesadaran akan pentingnya pemanfaatan lahan parkir yang tersedia.

\section{$>$ Penentuan Satuan ruang Parkir}

Berdasarkan Tabel 2.1 maka kebutuhan satuan ruang parkir kendaraan untuk luas kawasan obyek wisata Pantai Lasiana Kupang 3,5 ha atau $35.000 \mathrm{~m}^{2}$, setelah diinterpolasi sebesar 140 satuan ruang parkir. Lahan parkir permanen yang tersedia dalam kawasan ini ada dua lokasi dengan ukuran sebagai berikut: lokasi lahan parkir pertama ukuran 100 x 40 $\mathrm{m}^{2}$ dan lokasi lahan parkir kedua ukuran $25 \mathrm{x}$ $50 \mathrm{~m}^{2}$.
Lokasi lahan pertama menyediakan 101,5 satuan ruang parkir. Lokasi lahan parkir kedua menyediakan 98,11 satuan ruang parkir.

\section{$>$ Perhitungan Pendapatan Parkir}

Penerapan sistem tarif parkir dalam kawasan obyek wisata Pantai Lasiana Kupang ini menggunakan sistem tetap, yaitu sistem pembayaran besaran tarif yang tidak membedakan lama waktu parkir dari suatu kendaraan. Dalam analisa ini dibahas seluruh kendaraan yang masuk dalam area Obyek wisata Pantai Lasiana Kupang.

Jika diterapkan tarif parkir dengan sistem kombinasi yaitu sistem tetap dan tarif parkir sistem berubah sesuai waktu (progresif) dimana Sistem Berubah Sesuai Waktu (Progresif), sistem pembayaran besaran tarif yang memperhatikan lama waktu parkir suatu kendaraan, maka akan didapat bentuk pendapatan seperti tertera dalam Tabel 4 dan Tabel.5. Besar tarif progresif dihitung sebagai berikut : satu jam parkir = tarif tetap awal. Parkir Dua jam = tarif satu jam parkir ditambah (tarif tetap awal x 50\%). Tiga jam parkir $=$ tarif parkir dua jam ditambah (tarif tetap awal x 50\%), dan seterusnya. 
Tabel 4. Perhitungan Pendapatan Parkir Total (Kombinasi tarif tetap dan progresif) tgl 07-8-2016 s/d 28-8-2016.

\begin{tabular}{|l|r|r|r|r|}
\hline \multicolumn{5}{|l|}{ Mobil } \\
\hline $\begin{array}{c}\text { Durasi } \\
\text { (jam) }\end{array}$ & $\begin{array}{c}\text { Jumlah } \\
\text { kendaraan }\end{array}$ & Tarif tetap (Rp) & $\begin{array}{c}\text { Tarif progresif } \\
\text { (Rp) }\end{array}$ & $\begin{array}{c}\text { Pendapatan } \\
\text { (Rp) }\end{array}$ \\
\hline $\mathrm{x}<1$ & 324 & $648.000,00$ & & $648.000,00$ \\
\hline $1<\mathrm{x}<2$ & 187 & $374.000,00$ & $93.500,00$ & $467.500,00$ \\
\hline $2<\mathrm{x}<3$ & 52 & $104.000,00$ & $52.000,00$ & $156.000,00$ \\
\hline $3<\mathrm{x}<4$ & 32 & $64.000,00$ & $48.000,00$ & $112.000,00$ \\
\hline $4<\mathrm{x}<5$ & 14 & $28.000,00$ & $28.000,00$ & $56.000,00$ \\
\hline $5<\mathrm{x}<6$ & 8 & $16.000,00$ & $20.000,00$ & $36.000,00$ \\
\hline Total -1 & 617 & $1.234 .000,00$ & $241.500,00$ & $1.475 .500,00$ \\
\hline Sepeda Motor & \multicolumn{5}{|l|}{} \\
\hline $\mathrm{x}<1$ & 749 & $749.000,00$ & & $749.000,00$ \\
\hline $1<\mathrm{x}<2$ & 375 & $375.000,00$ & $187.500,00$ & $562.500,00$ \\
\hline $2<\mathrm{x}<3$ & 131 & $131.000,00$ & $131.000,00$ & $262.000,00$ \\
\hline $3<\mathrm{x}<4$ & 53 & $53.000,00$ & $79.500,00$ & $132.500,00$ \\
\hline $4<\mathrm{x}<5$ & 18 & $18.000,00$ & $36.000,00$ & $54.000,00$ \\
\hline $5<\mathrm{x}<6$ & 9 & $9.000,00$ & $22.500,00$ & $31.500,00$ \\
\hline Total -2 & 1.335 & $1.335 .000,00$ & $456.500,00$ & $1.791 .500,00$ \\
\hline Total & 1.952 & $2.569 .000,00$ & $698.000,00$ & $\mathbf{3 . 2 6 7 . 0 0 0 , 0 0}$ \\
\hline
\end{tabular}

Sumber : Hasil Perhitungan

Tabel .5 Perhitungan Pendapatan Parkir Rata-rata (Kombinasi tarif tetap dan progresif) tgl 07-8-2016 s/d 28-8-201

\begin{tabular}{|l|r|r|r|r|}
\hline \multicolumn{1}{|l|}{ Mobil } \\
\hline $\begin{array}{c}\text { Durasi } \\
\text { (jam) }\end{array}$ & $\begin{array}{c}\text { Jumlah } \\
\text { kendaraan }\end{array}$ & Tarif tetap (Rp) & $\begin{array}{c}\text { Tarif progresif } \\
\text { (Rp) }\end{array}$ & $\begin{array}{c}\text { Pendapatan } \\
\text { (Rp) }\end{array}$ \\
\hline $\mathrm{x}<1$ & 40,5 & $81.000,00$ & & $81.000,00$ \\
\hline $1<\mathrm{x}<2$ & 23,375 & $46.750,00$ & $11.687,50$ & $58.437,50$ \\
\hline $2<\mathrm{x}<3$ & 6,5 & $13.000,00$ & $6.500,00$ & $19.500,00$ \\
\hline $3<\mathrm{x}<4$ & 4 & $8.000,00$ & $6.000,00$ & $14.000,00$ \\
\hline $4<\mathrm{x}<5$ & 1,75 & $3.500,00$ & $3.500,00$ & $7.000,00$ \\
\hline $5<\mathrm{x}<6$ & 1 & $2.000,00$ & $2.500,00$ & $4.500,00$ \\
\hline Total -1 & 77 & $154.250,00$ & $30.187,50$ & $184.437,50$ \\
\hline
\end{tabular}

Sepeda Motor

\begin{tabular}{|l|r|r|r|r|}
\hline$x<1$ & 93,625 & $93.625,00$ & & $93.625,00$ \\
\hline $1<x<2$ & 46,875 & $46.875,00$ & $23.437,50$ & $90.312,50$ \\
\hline
\end{tabular}

\begin{tabular}{|l|r|r|r|r|}
\hline $1<x<2$ & 46,875 & $46.875,00$ & $23.437,50$ & $70.312,50$ \\
\hline $2<x<3$ & 16,375 & $16.375,00$ & $16.375,00$ & $32.750,00$ \\
\hline
\end{tabular}

\begin{tabular}{|l|r|r|r|r|}
\hline $2<x<3$ & 16,375 & $16.375,00$ & $16.375,00$ & $32.750,00$ \\
\hline $3<x<4$ & 6,625 & $6.625,00$ & $9.937,50$ & $16.562,50$ \\
\hline
\end{tabular}

\begin{tabular}{|l|r|r|r|r|}
\hline $3<\mathrm{x}<4$ & 6,625 & $6.625,00$ & $9.937,50$ & $16.562,50$ \\
\hline $4<\mathrm{x}<5$ & 2,25 & $2.250,00$ & $4.500,00$ & \\
\hline
\end{tabular}

\begin{tabular}{|l|r|r|r|r|}
\hline $4<x<5$ & 2,25 & $2.250,00$ & $4.500,00$ & $6.750,00$ \\
\hline $5<x<6$ & 1,125 & $1.125,00$ & $2.812,50$ & $3.937,50$ \\
\hline
\end{tabular}

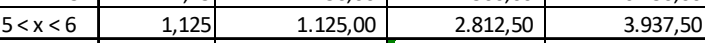

\begin{tabular}{|l|r|r|r|r|}
\hline Total -2 & 167 & $166.875,00$ & $57.062,50$ & $223.937,50$ \\
\hline
\end{tabular}

\begin{tabular}{|l|r|r|r|r|}
\hline Total & 244 & $321.125,00$ & $87.250,00$ & $\mathbf{4 0 8 . 3 7 5 , 0 0}$ \\
\hline
\end{tabular}

\begin{tabular}{l|r|r|r|}
\hline Satu Tahun & $117.210 .625,00$ & $31.846 .250,00$ & $149.056 .875,00$ \\
\hline
\end{tabular}

Sumber : Hasil Perhitungan
Volume 2 Nomor 1 April 2017

Besar tarif pendapatan ini akan meningkatkan pendapatan asli daerah propinsi Nusa Tenggara Timur. Penjaga parkir dapat menggunakan jasa masyarakat sekitar dengan memberi upah dari besar tarif progresif. Besar upahnya sesuai upah minimum regional Nusa Tenggara Timur.

\section{> Pendapatan Ekonomi Masyarakat sekitar}

Masyarakat sekitar kawasan obyek wisata Pantai Lasiana Kupang bisa dilibatkan dalam menjaga dan mengatur parkiran kendaraan di lahan parkir permanen yang tersedia. Perhitungan pendapatan masyarakat menggunakan upah minimum regional. Upah minimum regional Propinsi Nusa Tenggara Timur dalam Tahun 2016 sebesar Rp. 1.425.000,- per bulan. Jika dihitung per hari menjadi Rp. 46.000. Besar dana ini dibayarkan dari pendapatan parkir tarif progresif kendaraan yang masuk per hari.

Berdasarkan Tabel 5 setiap kendaraan masuk untuk parkir, sampai keluar, tukang parkir dihargai sebesar $=$ Rp. $46.000 / 244$ kendaraan $=$ Rp. 189,3,- per kendaraan, dibulatkan sampai Rp. 190 per kendaraan. Sehingga jika ada 244 kendaraan masuk seperti dalam Tabel .5 petugas parkir diberi upah sebesar $=$ Rp.46.170. Sehingga dalam seminggu petugas parkir diberi upah sebesar Rp. 323.190,-.

Apabila dalam sebulan menjadi Rp. 1.431.270. Dalam Tabel . 5, sisa dana tarif parkir progresif dalam sebulan $=(\mathrm{Rp} .87 .250$ per hari x 31 hari) - Rp.1.431.270 = Rp. 1.273.480. Sisa dana tarif progresif ini ditambah dana tarif tetap per hari sebesar Rp. 321.125 masuk ke kas pendapatan asli daerah Propinsi Nusa Tenggara Timur. 


\section{$>$ Rekapitulasi kuesioner}

Pembahasan Fasilitas dan Tempat Parkir :

\begin{tabular}{|c|c|c|c|c|c|c|}
\hline \multirow{2}{*}{ No. } & \multirow{2}{*}{ Pertanyaan } & \multicolumn{5}{|c|}{ Pilihan Jawaban } \\
\hline & & 1 & 2 & 3 & 4 & 5 \\
\hline 1 & $\begin{array}{l}\text { Lahan parkir yang tersedia di kawasan obyek wisata Pantai } \\
\text { Lasiana Kupang cukup memadai }\end{array}$ & $\mathrm{O}$ & $\mathrm{O}$ & $\mathrm{O}$ & $\mathrm{O}$ & $\mathrm{O}$ \\
\hline 2 & $\begin{array}{l}\text { Lahan parkir yang tersedia di kawasan obyek wisata Pantai } \\
\text { Lasiana Kupang cukup representatif }\end{array}$ & $\mathrm{O}$ & $\mathrm{O}$ & $\mathrm{O}$ & $\mathrm{O}$ & O \\
\hline 3 & $\begin{array}{l}\text { Terdapat pengelompokan area parkir untuk sepeda motor dan } \\
\text { mobil }\end{array}$ & $\mathrm{O}$ & $\mathrm{O}$ & $\mathrm{O}$ & $\mathrm{O}$ & O \\
\hline 4 & Area parkir yang ada bersih dan teratur & $\mathrm{O}$ & $\mathrm{O}$ & $\mathrm{O}$ & $\mathrm{O}$ & $\mathrm{O}$ \\
\hline 5 & Petugas parkir mengatur/menata kendaraan dengan baik & $\mathrm{O}$ & $\mathrm{O}$ & $\mathrm{O}$ & $\mathrm{O}$ & $\mathrm{O}$ \\
\hline 6 & Adanya sistem pengamanan parkir yang baik & $\mathrm{O}$ & $\mathrm{O}$ & $\mathrm{O}$ & $\mathrm{O}$ & $\mathrm{O}$ \\
\hline 7 & $\begin{array}{l}\text { Tingkat kehilangan atribut kendaraan (helm, jaket dll) sangat } \\
\text { kecil }\end{array}$ & $\mathrm{O}$ & $\mathrm{O}$ & $\mathrm{O}$ & $\mathrm{O}$ & $\mathrm{O}$ \\
\hline 8 & $\begin{array}{l}\text { Masih terdapat alternatif lahan parkir untuk kegiatan-kegiatan } \\
\text { publik dalam kawasan obyek wisata Pantai Lasiana Kupang }\end{array}$ & $\mathrm{O}$ & $\mathrm{O}$ & $\mathrm{O}$ & $\mathrm{O}$ & $\mathrm{O}$ \\
\hline
\end{tabular}

Keterangan : Ada lima alternatif jawaban yang dapat saudara pilih, yaitu :

1 = Tidak Memuaskan ; 2 = Kurang Memuaskan; 3 = Cukup Memuaskan;

4 = Memuaskan; 5 = Sangat Memuaskan

Lahan yang tersedia dianggap cukup memadai dan representatif itu dijawab oleh 44 responden (42\%), sementara yang memilih kurang dan bahkan masih kurang sebanyak 5,7\% (6 responden). Selebihnya memilih lebih dari cukup. Responden yang memilih pengelompokkan area parkir belum sesuai jenis kendaraan sebesar $34,3 \% \quad$ (36 responden), sisanya memilih cukup dan bahkan lebih memuaskan.

Responden yang memilih kurang memuaskan dan bahkan sangat kurang memuaskan dari sisi kebersihan area parkir dan petugas parkir yang mengatur kendaraan parkir sebesar 63\% (66 responden). Sisanya memilih cukup dan baik. $80 \%$ responden $(84$ responden) yang memilih masih kurang memuaskan dan bahkan tidak memuaskan sistem pengaman parkir yang baik, sisanya memilih cukup dan baik.
Tingkat kehilangan atribut di tempat wisata responden yang memilih kurang memuaskan dan bahkan tidak memuaskan sebanyak $27,62 \%$ (29 res ponden), sisanya memilih cukup dan bahkan baik. Masih terdapat alternatif lahan parkir dalam kawasan Pantai Lasiana, responden yang memilih sangat dan kurang memuaskan sebesar 26,7 \% (28 Responden ) sedangkan sisanya memilih cukup dan di atas cukup.

Kuesioner lanjutan :

1.Transportasi apa yang anda gunakan untuk menuju ke Obyek Wisata Pantai Lasiana Kupang?
A. Mobil
B. Motor
C. Kendaraan umum
D. Jalan kaki
E. Lain-lain 


\section{4 | JUTEKS Jurnal Teknik Sipil Volume 2 Nomor 1 April 2017}

2.Apakah anda mengetahui tentang jumlah lahan parkir di Obyek Wisata Pantai Lasiana Kupang?
A. Ya
B. Tidak

3.Berapa jumlah lahan parkir yang tersedia?

4.Dimanakah kendaraan Anda diparkirkan dalam kawasan Obyek Wisata Pantai Lasiana Kupang?

Menurut anda bagaimana fasilitas parkir di Obyek Wisata Pantai Lasiana Kupang saat ini?
A. Baik
B. Cukup
C. Kurang

5.Apa harapan anda terkait ketersediaan fasilitas lahan parkir ini setelah adanya renovasi yang sementara dikerjakan?

Sebanyak 23\% (19 responden ) yang tidak tahu jumlah dan tempat parkir dalam kawasan obyek wisata Pantai Lasiana Kupang. Sebanyak 20\% (17 responden) yang memarkir kendaraan tidak di tempat parkir, sisanya parkir di tempat parkir yang tersedia. Sebanyak 5\% (4 responden) memilih kurang fasilitas parkir dalam kawasan wisata ini. Harapan pengunjung yang menggunakan kendaraan ke obyek wisata adalah kiranya fasilitas parkir ditata lebih baik lagi supaya ke depan kendaraan parkir sesuai tempat jenis peruntukkannya.

\section{KESIMPULAN}

Dari hasil penelitian ini, ada beberapa kesimpulan yaitu :

1.Pengunjung ke lokasi wisata Pantai Lasiana Kupang ini lebih banyak menggunakan kendaraan, ketimbang berjalan kaki.

2.Kendaraan banyak yang masuk dan keluar lokasi obyek wisata Pantai Lasiana Kupang ini.

a. Kendaraan beroda dua (sepeda motor) lebih dominan masuk dan keluar di lokasi obyek wisata Pantai Lasiana Kupang, dengan prosentase berkisar $60,5 \%$ sampai $78,4 \%$ untuk jenis sepeda motor, sementara $21,4 \%$ sampai 39,5\% untuk kendaraan jenis mobil.
b.Kendaraan yang parkir sembarang untuk sepeda motor sebesar $44 \%$, dan mobil 53\%.

c. Durasi rata-rata parkir mobil 55,91 menit, sepeda motor 68,90 menit.

d.Tersedia 200 satuan ruang parkir dalam kawasan obyek wisata Pantai Lasiana Kupang.

e.Pendapatan pemerintah melalui tarif parkir dalam setahun Rp. 149.056.875.

f. Pendapatan tukang parkir Rp. 1.431.270. per bulan.

g. $63 \%$ responden memilih kurang bersih dan tidak ada petugas parkir $80 \%$ responden memilih kurang memuaskan sistem pengaman parkir yang baik.

3.Salah satu lokasi lahan parkir permanen yang ada dipakai sebagai tempat base camp bagi kontraktor beraktifitas merenovasi kawasan pantai Lasiana Kupang.

4.Kawasan obyek wisata ini hanya ramai dikunjungi pada hari libur saja.

\section{DAFTAR PUSTAKA}

Abubakar, dkk, 1999, Rekayasa Lalu Lintas, Direktorat Bina Sistem Lalu Lintas dan Angkutan Kota, Jakarta.

Anonim, 1998, Pedoman Perencanaan dan Pengoperasian Fasilitas Parkir. Direktorat Bina Sistem Lalu Lintas dan Angkutan Kota, Jakarta.

Anonim, 2008, Kamus Besar Bahasa Indonesia (online), Jakarta, .http://pusatbahasa. kemdiknas.go.id/kbbi/, Berkunjung pada tanggal 12 April 2013.

Anonim, 2013, Parkir (online), http:// id.wikipedia.org/wiki/Parkir, Berkunjung pada tanggal 6-4-2013.

Munawar, A, 1998, Manajemen Lalu Lintas Perkotaan, Penerbit Beta Offset, Yogyakarta. 
Putri, S,N, 2011, Efektifitas Pelayanan Pelabuhan Oleh PT. ASDP (Persero) Merak Propinsi Banten, Skripsi, Fakultas Ilmu Sosial dan Ilmu Politik, Universitas Sultan Ageng Tirtayasa, Banten.

Soleman, M.2012. Pesona Pantai Lasiana Kupang (online),

http://info.tnial.mil.id/lantamal7/tabid/367/ articleType/ArticleView/articleId/473/ PE S ON A - PA N T A I - L A S I A N A KUPANG.aspx
Berkunjung pada website ini tanggal 15 Maret 2013.

Sonder, I Wayan, 2009, Pengembangan Kawasan Pariwisata Pantai Lasiana Menuju Pariwisata Berkelanjutan Di Kota Kupang, Universitas Udayana, Denpasar. 